\title{
Accuracy Assessment of Alos W3d30, Aster Gdem and Srtm30 Dem: A Case Study of Nigeria, West Africa
}

\author{
O. I. Apeh", V. N. Uzodinma, E. S. Ebinne, E. C. Moka, E. U. Onah \\ Department of Geoinformatics \& Surveying, University of Nigeria, Enugu Campus, Nigeria \\ Email: *ojima.apeh@unn.edu.ng, *apehisaac@yahoo.com
}

How to cite this paper: Apeh, O.I., Uzodinma, V.N., Ebinne, E.S., Moka, E.C. and Onah, E.U. (2019) Accuracy Assessment of Alos W3d30, Aster Gdem and Srtm30 Dem: A Case Study of Nigeria, West Africa. Journal of Geographic Information System, $11,111-123$.

https://doi.org/10.4236/igis.2019.112009

Received: February 14, 2019

Accepted: March 12, 2019

Published: March 15, 2019

Copyright $\odot 2019$ by author(s) and Scientific Research Publishing Inc. This work is licensed under the Creative Commons Attribution International License (CC BY 4.0).

http://creativecommons.org/licenses/by/4.0/

\section{(c) (i) Open Access}

\begin{abstract}
Digital Elevation Models (DEMs) depict the configuration of the earth surface and are being applied in many areas in earth and environmental sciences. In this study, the accuracy of the Advanced Land Observing Satellite World 3D Digital Surface Model version 2.1 (ALOS W3D30), the Shuttle Radar Topography Mission Digital Elevation Model version 3.0 (SRTM30) and the Advanced Space borne Thermal Emission and Reflection Radiometer Global DEM version 2.0 (ASTER GDEM2) was statistically assessed using high accuracy GPS survey data. Root-Mean-Square errors of $\sim 5.40 \mathrm{~m}, \sim 7.47 \mathrm{~m}$ and $\sim 20.03 \mathrm{~m}$ were obtained for ALOS W3D30, SRTM30 and ASTER GDEM2 respectively. In further analyses, we discovered that ALOS W3D30 and SRTM30 were much more accurate in regions where the height intervals were within $201 \mathrm{~m}-400 \mathrm{~m}$ and $>801 \mathrm{~m}$. ALOS W3D30 proved to be the most accurate DEM that best represents the topography of the earth's surface and could be used for some earth and environmental applications in Nigeria. We recommend that this study should serve as a guide in the use of any of these DEMs for earth and environmental applications in Nigeria.
\end{abstract}

\section{Keywords}

ALOS W3D30, ASTER GDEM2, SRTM30, Nigeria, DEMs, Accuracy

Assessment, Root-Mean-Square Error

\section{Introduction}

Digital Elevation Models (three-dimensional representation of the earth surface) are chief sources of height information which are greatly applied in many disciplines. Many areas where DEMs are applied include: flood inundation modeling 
[1]; vegetation mapping [2] [3]; mapping of Coral Reef Environments [4]; development of Geopotential Global Models [5]; evaluation of glacier volume change [6]; navigation systems for commercial aviation [7]; climatic modeling [8]; archeology [9]; glacier surface change [10]; hydrological analysis and simulations [11]; soil science and geology [12]; Catchment Geomorphology and Hydrology [13]; and monitoring coastal erosions and sedimentations [14]. In another study, the author further categorized the various areas where global or near global DEMs can be applied [15].

It is true that DEMs have become very useful sources of data for a range of applications in Earth and environmental sciences [16] but despite their usefulness, there are many sources of errors inherent in them [17]. Owing to this fact, and as a result of recent improvement and release of newer versions of the Advanced Land Observing Satellite World 3D Digital Surface Model version 2.1 (ALOS W3D30); the Shuttle Radar Topography Mission Digital Elevation Model version 3.0 (SRTM30) and the Advanced Spaceborne Thermal Emission and Reflection Radiometer Global DEM version 2.0 (ASTER GDEM2), it is very important to assess and compare the quality of these data in order to see how well the DEMs fit the locally available or acquired data. This will help in determining the size of their errors within an area of application.

Several researchers [15] [17]-[24] from different regions of the world assessed the accuracy or fitness of these DEMs with respect to their locally available or acquired data and reported the most accurate DEM in their region. Table 1 presents the results obtained by these authors from different countries of the world. Although ALOS W3D30 is reported as the most accurate DEM in almost all the studies, there is need to determine its actual level of accuracy per study area since the studies show varying levels of accuracy. This is because the accuracy of DEMs depends on region of study, nature of environment, methods of algorithm development, input data, data processing and the resolution of the sensor. For example from Table 1, the RMSE of ALOS W3D30 in Philippines, Cameron and Russia is $5.68 \mathrm{~m}, 13.06 \mathrm{~m}$ and $7.87 \mathrm{~m}$ respectively.

Presently, there is no readily available topographic map that can easily provide topographic information for various scientific applications in Nigeria and it is a well known fact that terrestrial acquisition of geospatial data is more laborious, time-consuming and very expensive than doing same remotely. Although several studies have been carried out on the accuracy assessment of DEMs in different parts of the world, yet there is no comprehensive study on the vertical accuracy of these freely available DEMs over Nigeria. This is despite the fact that these DEMs are being used as chief sources of topographic information for numerous applications in earth and environmental sciences. This study, therefore, is aimed at assessing the accuracy of these DEMs over Nigeria by using terrestrially acquired GPS (Global Positioning System) survey data since it provides an independent way of assessing the quality of these three DEMs over Nigeria. This validation will also serve as a feedback to the research groups and/or gov- 
ernment agencies that developed these DEMs and it is intended to complement all the other studies that have been carried out in other countries to assess their quality.

\section{Materials and Method}

\subsection{Data Sets}

The data sets used in this study are: sixty five (65) GPS points, ALOS W3D30, SRTM30 and ASTER GDEM2. The sixty five (65) GPS points are geodetic coordinates which form part of Nigerian geodetic network. The ellipsoidal heights range from $22.84 \mathrm{~m}$ to $1793.41 \mathrm{~m}$. The Root-Mean-Square Errors (RMSE) of the ellipsoidal heights at the reference epoch, (01. JAN.2012), range from $0.00101 \mathrm{~m}$ to $0.0244 \mathrm{~m}$ for the sixty five (65) GPS points. These GPS points were obtained from the Office of Surveyor General of the Federation (OSGoF) in Nigeria. Figure 1 shows the distribution of the GPS points over Nigeria.

We downloaded related portions of the ALOS W3D30 DSM [25], SRTM30 DEM and ASTER GDEM2 [26] over Nigeria. The Raster values (heights) of these DEMs were extracted to the coordinates of the GPS points. These heights are referred to as heights obtained from each of the DEMs. Table 2 gives a summary of the characteristics of the DEMs used.

Table 1. Results obtained from other regions.

\begin{tabular}{|c|c|c|c|c|}
\hline COUNTRY & Authors & STD & RMSE & Sample_Points \\
\hline Croatia & [17] & & $\begin{array}{l}\text { SRTM }=3.8 \mathrm{~m} \\
\text { ASTER }=7.1 \mathrm{~m}\end{array}$ & 7725 \\
\hline Philippines & {$[18]$} & & $\begin{aligned} \text { SRTM } & =8.28 \mathrm{~m} \\
\text { ASTER } & =11.98 \mathrm{~m} \\
\text { ALOS } & =5.68 \mathrm{~m}\end{aligned}$ & 274 \\
\hline Ca meron & {$[15]$} & & $\begin{array}{l}\text { SRTM }=13.25 \mathrm{~m} \\
\text { ASTER }=18.87 \mathrm{~m} \\
\text { ALOS }=13.06 \mathrm{~m}\end{array}$ & 555 \\
\hline Russia & [22] & & $\begin{array}{l}\text { SRTM }=17.91 \mathrm{~m} \\
\text { ASTER }=9.1 \mathrm{~m} \\
\text { ALOS }=7.87 \mathrm{~m}\end{array}$ & 69 \\
\hline Argentina & [20] & $\begin{aligned} \text { ASTER } & =9.48 \mathrm{~m} \\
\text { ALOS } & =2.81 \mathrm{~m}\end{aligned}$ & & 307,509 \\
\hline Egypt & [23] & $\begin{array}{l}\mathrm{SRTM}=2.6 \mathrm{~m} \\
\mathrm{ASTER}=5.7 \mathrm{~m} \\
\mathrm{ALOS}=2.4 \mathrm{~m}\end{array}$ & & 416 \\
\hline Saudi Arabia & [23] [24] & $\begin{aligned} \mathrm{SRTM} & =6.8 \mathrm{~m} \\
\mathrm{ASTER} & =6.9 \mathrm{~m} \\
\mathrm{ALOS} & =6.8 \mathrm{~m}\end{aligned}$ & $\begin{array}{l}\mathrm{SRTM}=7.92 \mathrm{~m} \\
\mathrm{ASTER}=7.45 \mathrm{~m}\end{array}$ & $137 ; 50$ \\
\hline
\end{tabular}


Table 2. Summary of the DEMs used.

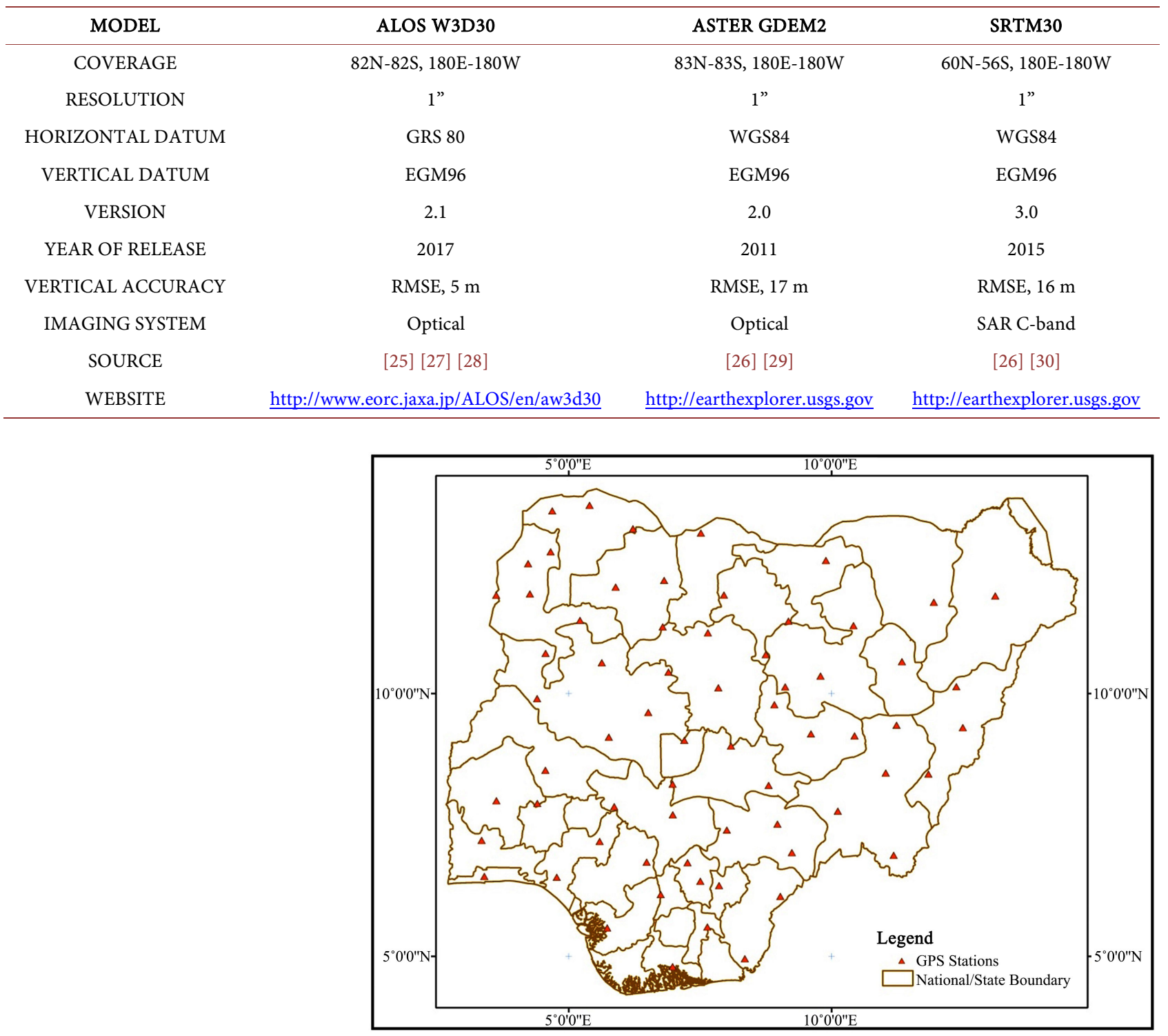

Figure 1. Distribution of GPS points over Nigeria.

\subsection{Methods of Accuracy Assessment}

As presented in Table 2, heights obtained from these three DEMs are vertically referenced to the Earth Gravitational Model 1996 (EGM96) and this led to the transformation of ellipsoidal heights using geoid undulations computed from EGM96 [31]. Mathematically, Equation (2) shows the relationship between ellipsoidal height and EGM96 derived height:

$$
\mathrm{h}^{\mathrm{GPS}}-\mathrm{N}^{\mathrm{EGM} 96}=\mathrm{H}^{\mathrm{Ortho}}
$$

where: $\mathrm{h}^{\mathrm{GPS}}=$ Ellipsoidal height

$\mathrm{N}^{\mathrm{EGM} 96}=$ Geoid undulation derived from EGM96, $\mathrm{H}^{\text {Ortho }}=$ height derived from EGM96.

The Mean error (Equation (2)), standard deviation error (Equation (3)), 
Root-Mean-Square Error (Equation (4)), and correlation coefficient (Equation (5)) are the statistical tools that were used in assessing the vertical accuracy of the heights obtained from these three DEMs as adopted by other researchers [32] [33] [34] [35]. The differences in heights obtained from each of the DEMs and GPS points are referred to as "errors" on the ground that the terrestrially acquired GPS points are of higher accuracy.

$$
\operatorname{ME}(\text { Mean Error })=\frac{\sum_{i=1}^{\mathrm{N}}(\mathrm{E})}{\mathrm{N}}
$$

where; $\mathrm{E}=$ Error $=\mathrm{H}^{\mathrm{GPS}}-\mathrm{H}^{\mathrm{DEM}}, \mathrm{H}^{\mathrm{GPS}}=$ EGM96-derived heights from the GPS survey data, $\mathrm{H}^{\text {DEM }}=$ heights obtained from each of the DEMs, $\mathrm{N}=$ number of test points.

$$
\begin{gathered}
\operatorname{STDE}\left(\text { Standard Deviation Error) }=\sqrt{\frac{\sum_{i=1}^{\mathrm{N}}(\mathrm{E}-\mathrm{ME})^{2}}{\mathrm{~N}-1}}\right. \\
\text { RMSE (Root-Mean-Square Error) }=\sqrt{\frac{\sum_{i=1}^{\mathrm{N}}\left(\mathrm{E}^{2}\right)}{\mathrm{N}}}
\end{gathered}
$$

The closer the value of the RMSE to zero, the more accurate are the heights obtained from DEMs while the farther the value of the RMSE from zero, the less accurate are the heights obtained from DEMs.

$$
\operatorname{Correl}(X, Y)=\frac{\sum(x-\bar{x})(y-\bar{y})}{\sqrt{\sum(x-\bar{x})^{2} \sum(y-\bar{y})^{2}}}
$$

where; $X=$ EGM96-derived heights from the GPS survey data, Correl = Correlation Coefficient, $Y=$ heights obtained from each of the DEMs, $\bar{x}$ and $\bar{y}$ are sample means.

The closer the value of correlation coefficient to \pm 1 , the more the level of agreement of the heights obtained from each of the DEMs are to EGM96-derived heights from the GPS survey data and vice versa.

Furthermore, the Linear Errors (LE) of each of the three DEMs were calculated at 90\% (Equation (6)), 95\% (Equation (7)) and 99.73\% (Equation (8)) confidence levels on the assumption that the vertical errors are normally distributed and that the linear errors are directly proportional to the standard deviation errors [35] [36].

$$
\begin{gathered}
\mathrm{LE} @ 90 \%=1.6449 \times \mathrm{STDE} \\
\mathrm{LE} @ 95 \%=1.9000 \times \mathrm{STDE} \\
\mathrm{LE} @ 99.73 \%=3.0000 \times \mathrm{STDE}
\end{gathered}
$$

The sixty five (65) GPS points and each of the corresponding heights obtained from the three DEMs were classified into $200 \mathrm{~m}$ height intervals for a more intensive performance evaluation of the DEMs. The height intervals are $0-200 \mathrm{~m}$, $201-400 \mathrm{~m}, 401-600 \mathrm{~m}, 601-800 \mathrm{~m}$ and $>800 \mathrm{~m}$. The statistical results obtained from each of these classes were used to assess the effect of the undulating terrain on the vertical accuracy of each of the three DEMs. 


\section{Results and Discussions}

The EGM96-derived geoid undulations at the sixty five (65) GPS stations are shown in Figure 2. These were the values subtracted from the ellipsoidal heights at each of the sixty five (65) GPS points to obtain the heights referred to as EGM96-derived heights.

The EGM96-derived heights from the GPS survey data and the heights obtained from each of the DEMs are shown in Figure 3.

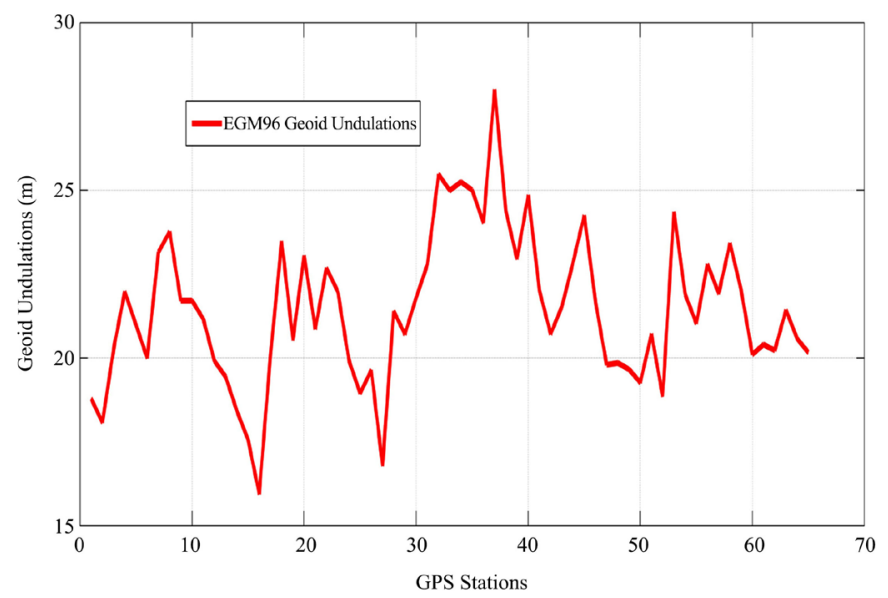

Figure 2. Geoid undulations.

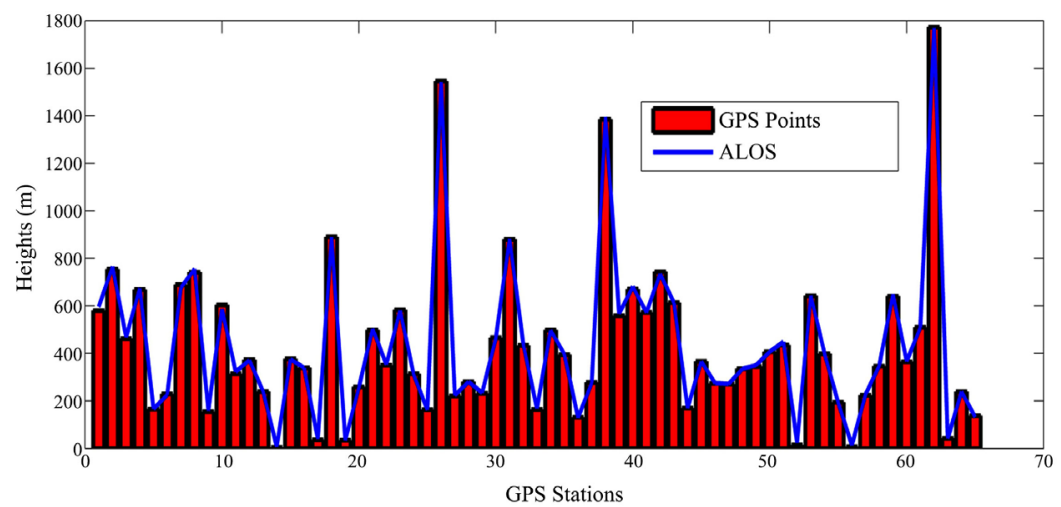

(a)

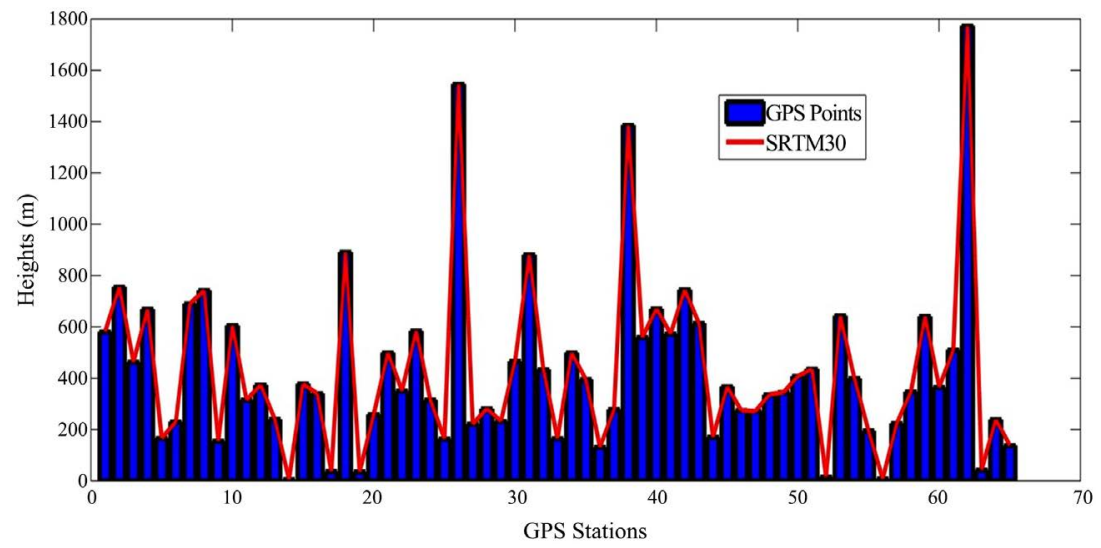

(b) 


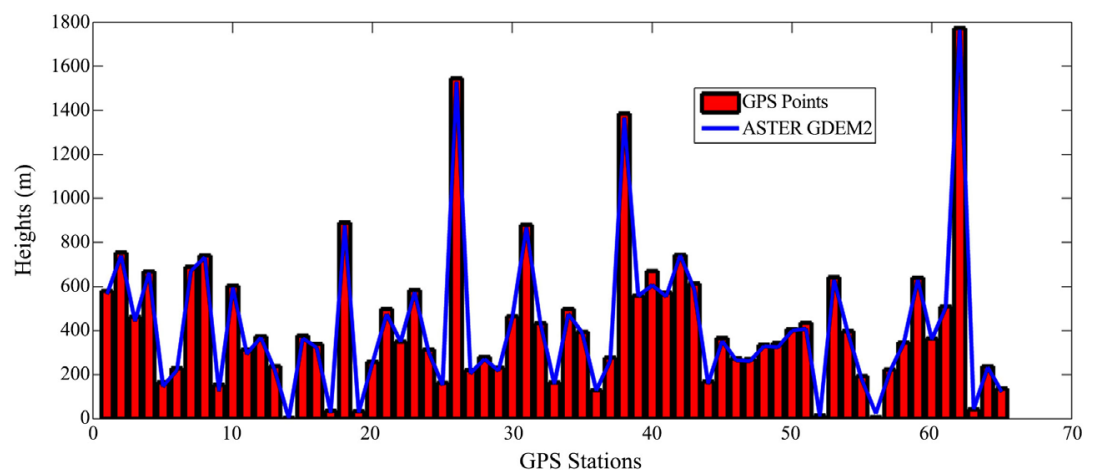

(c)

Figure 3. (a-c): Heights (a) GPS versus ALOS W3D30 (b) GPS versus SRTM30 (c) GPS versus ASTER GDEM2.

A closer look at Figure 3 reveals that there is a sharp difference at stations 42, 1 and 40 for ALOS W3D30, SRTM30 and ASTER GDEM2 respectively. These are the stations that have the maximum differences in heights between each DEM and the GPS points. The differences (errors) obtained in the heights between each of the DEMs and the sixty five (65) GPS points are shown in Figure 4. The statistical results of these errors are shown in Table 3. The coefficients of correlation between the EGM96-derived heights from the GPS survey data and that of ALOS W3D30, SRTM30 and ASTER GDEM2 are 0.9999, 0.9998 and 0.9993 respectively meaning that each of the DEMs are highly correlated to the EGM96-derived heights of the GPS points but ALOS W3D30 has the highest level of agreement.

From the results shown in Table 3, it can be inferred that ALOS W3D30 is more accurate than STRM30 and ASTER GDEM2 in Nigeria. Overall, the RMSE obtained from ALOS W3D30 is $40 \mathrm{~cm}$ different from the specified $5 \mathrm{~m}$ [28]. It is noteworthy that SRTM30 performed far better than the specified vertical accuracy of $16 \mathrm{~m}$.

Furthermore, the heights were classified into $200 \mathrm{~m}$ height intervals in order to detect the height interval that better fits the locally observed GPS survey data. The corresponding statistical results of the errors within each height interval are presented in Figure 5 while the linear errors are listed in Table 4.

At all the height intervals, ALOS W3D30 performed better in accuracy, followed closely by SRTM30 and lagging far behind is the ASTER GDEM2. As confirmed by other studies [15] [18] [22] [23] ALOS W3D30 is better in accuracy than the other two DEMs evaluated in Nigeria. This means that ALOS W3D30 best represents the topography of the earth's surface within the study area especially in regions where the height are $>801 \mathrm{~m}$.

There is a steady increase in the accuracy of ALOS W3D30 and SRTM30 at height intervals of $0-200 \mathrm{~m} ; 201-400 \mathrm{~m}$ and a sharp increase at $601-800 \mathrm{~m}$ and $>801 \mathrm{~m}$. This shows that regions or states, whose heights are within $201-$ $400 \mathrm{~m}$, have better terrain modeling by ALOS W3D30 than regions within 0 $200 \mathrm{~m} ; 401-600 \mathrm{~m}$ and $601-800 \mathrm{~m}$. Based on all the statistical values obtained 
at $601-800 \mathrm{~m}$ height interval, ALOS W3D30 and ASTER GDEM2 performed poorly with ALOS W3D30 having more than two times the expected accuracy while ASTER GDEM had almost twice its expected accuracy.

Although five (5) GPS points fell within the height interval of $>801 \mathrm{~m}$, ALOS W3D30 performed two and half times better than its expected accuracy, SRTM30 performed more than three times better than its expected accuracy while ASTRE GDEM2 stays within its expected accuracy. It is evident and as corroborated by other authors [15] [18] [22] [23] that vertical accuracy of global DEMs is greatly affected by the slope of the terrain. The linear errors (Table 4) computed from each height intervals confirmed the superiority of ALOS W3D30 to the other two DEMs evaluated in this study and this clearly shows that ALOS W3D30 can be used alone or in combination with terrestrial data for some earth and environmental applications.

Table 3. Statistical results of the errors.

\begin{tabular}{ccccccccc}
\hline DEMs & $\begin{array}{c}\text { MIN } \\
(\mathrm{m})\end{array}$ & $\begin{array}{c}\text { MAX } \\
(\mathrm{m})\end{array}$ & $\begin{array}{c}\text { ME } \\
(\mathrm{m})\end{array}$ & $\begin{array}{c}\text { STDE } \\
(\mathrm{m})\end{array}$ & $\begin{array}{c}\text { RMSE } \\
(\mathrm{m})\end{array}$ & $\begin{array}{c}\text { LE@90\% } \\
(\mathrm{m})\end{array}$ & $\begin{array}{c}\text { LE@95\% } \\
(\mathrm{m})\end{array}$ & $\frac{\text { LE@99.73\% }}{(\mathrm{m})}$ \\
\hline SRTM30 & -5.05 & 24.84 & 3.96 & 6.38 & 7.47 & 10.49 & 12.12 & 19.14 \\
ASTER GDEM2 & -5.05 & 76.95 & 15.45 & 12.85 & 20.03 & 21.14 & 24.42 & 38.55 \\
ALOS W3D30 & -3.45 & 20.29 & 2.88 & 4.60 & 5.40 & 7.57 & 8.74 & 13.80 \\
\hline
\end{tabular}

Table 4. Linear errors of the DEMs based on height intervals.

\begin{tabular}{|c|c|c|c|c|c|c|c|c|c|c|}
\hline \multirow{3}{*}{$\begin{array}{l}\text { Height } \\
\text { Intervals } \\
\quad(\mathrm{m})\end{array}$} & \multicolumn{10}{|c|}{ Confidence Levels } \\
\hline & \multirow{2}{*}{ Count } & \multicolumn{3}{|c|}{ LE@90\% (m) } & \multicolumn{3}{|c|}{$\underline{\mathrm{LE} @ 95 \%}$ (m) } & \multicolumn{3}{|c|}{ LE@99.73\% (m) } \\
\hline & & ALOS & ASTER & SRTM & ALOS & ASTER & SRTM & ALOS & ASTER & SRTM \\
\hline $0-200$ & 14 & 5.67 & 15.40 & 9.21 & 6.56 & 17.78 & 10.64 & 10.35 & 28.08 & 16.80 \\
\hline $201-400$ & 22 & 4.38 & 13.80 & 6.79 & 5.05 & 15.94 & 7.85 & 7.98 & 25.17 & 12.39 \\
\hline $401-600$ & 13 & 5.72 & 21.53 & 10.79 & 6.61 & 24.87 & 12.46 & 10.44 & 39.27 & 19.68 \\
\hline $601-800$ & 11 & 10.79 & 30.46 & 11.55 & 12.46 & 35.19 & 13.34 & 19.68 & 55.56 & 21.06 \\
\hline$>801$ & 5 & 1.86 & 13.85 & 7.42 & 2.15 & 16.00 & 8.57 & 3.39 & 25.26 & 13.53 \\
\hline
\end{tabular}

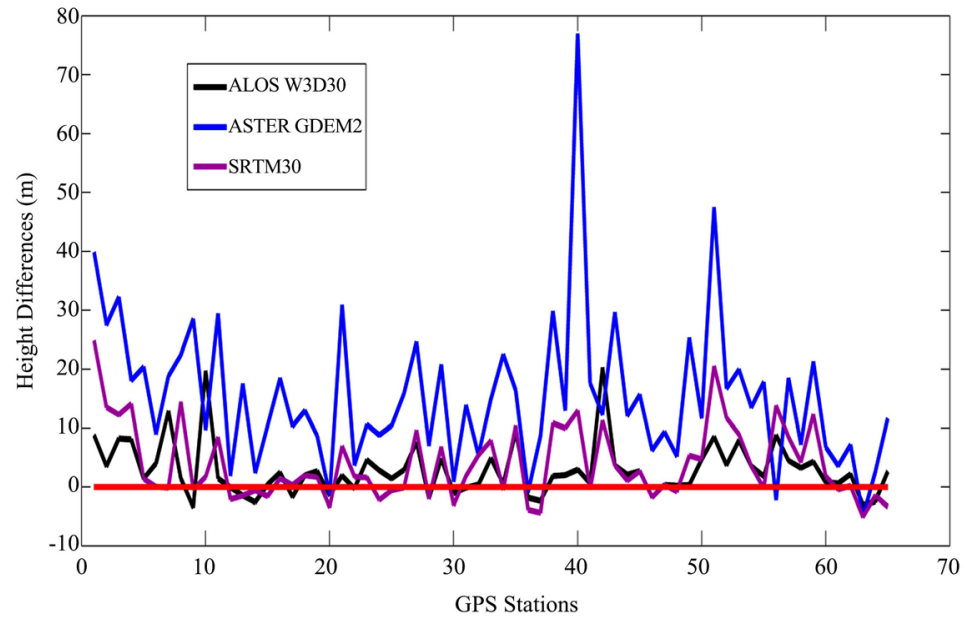

Figure 4. Errors in heights obtained from each of the DEMs. 


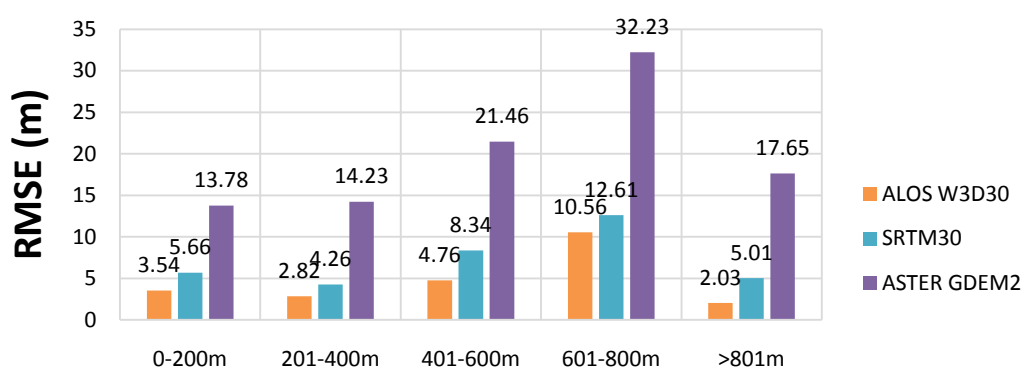

Height Intervals

(a)

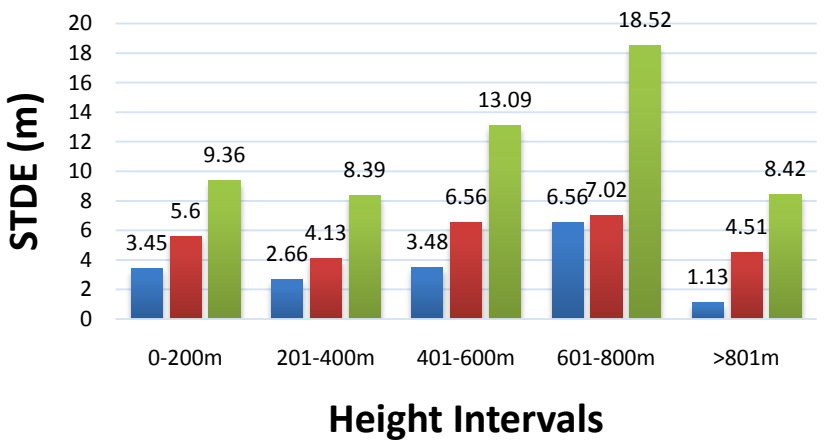

- ALOS W3D30

- SRTM30

- ASTER GDEM2

(b)

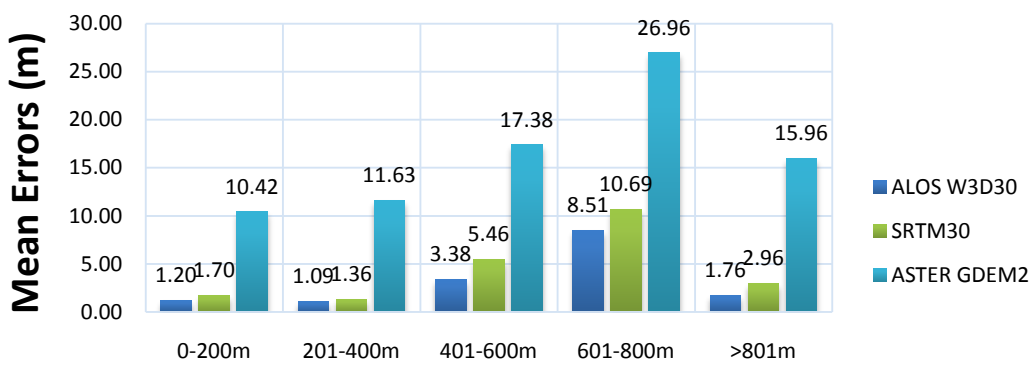

Height Intervals

(c)

Figure 5. (a-c) Statistical results of the height intervals (a) Root-Mean-Square Errors (b) Standard Deviation Errors (c) Mean Errors.

\section{Conclusions}

This study which aimed at assessing the quality of global or near global DEMS applied several statistical tools to determine the accuracy of heights obtained from ALOS W3D30, ASTER GDEM2 and SRTM30 using high accuracy GPS survey data over Nigeria. In all the analyses, ALOS W3D30 proved to be the most accurate DEM that can relatively depict the topography of the earth's surface in Nigeria. We discovered that regions or states, within the study area, where the height intervals are $>801 \mathrm{~m}$, have improved statistical results than others while regions within $601 \mathrm{~m}-800 \mathrm{~m}$ height interval have worse statistical results when using ALOS W3D30 in Nigeria. 
Accuracy assessment of DEMs is of utmost importance in earth and environmental sciences for it shows how the DEMs best approximate the dynamic earth surface. Generally, the accuracy of DEMs depends on region of study, nature of environment, methods of algorithm development, input data, data processing and the resolution of the sensor. This explains the varying levels of accuracy recorded by each of the DEMs. We, therefore, recommend that this study should serve as a guide in the use of any of these DEMs for earth and environmental applications in Nigeria.

\section{Acknowledgements}

The authors are very grateful to the Office of Surveyor General of the Federation (OSGoF) in Nigeria for providing the GPS survey data for this study.

\section{Conflicts of Interest}

The authors declare no conflicts of interest regarding the publication of this paper.

\section{References}

[1] Tarekegn, T.H. and Sayama, T. (2013) Correction of SRTM DEM Artefacts by Fourier Transform for Flood Inundation Modeling. Journal of Japan Society of Civil Engineers, Ser. B1 (Hydraulic Engineering), 69, I_193-I_198.

[2] Kellndorfer, J., Walker, W., Pierce, L., Dobson, C., Fites, J.A., Hunsaker, C. and Clutter, M. (2004) Vegetation Height Estimation from Shuttle Radar Topography Mission and National Elevation Datasets. Remote Sensing of Environment, 93, 339-358. https://doi.org/10.1016/j.rse.2004.07.017

[3] O’Loughlin, F.E., Paiva, R.C.D., Durand, M., Alsdorf, D.E. and Bates, P.D. (2016) A Multi-Sensor Approach towards a Global Vegetation Corrected SRTM DEM Product. Remote Sensing of Environment, 182, 49-59.

https://doi.org/10.1016/j.rse.2016.04.018

[4] Hamylton, S.M. (2017) Mapping Coral Reef Environments: A Review of Historical Methods, Recent Advances and Future Opportunities. Progress in Physical Geography, 41, 803-833. https://doi.org/10.1177/0309133317744998

[5] Arabelos, D. (2000). Intercomparisons of the Global DTMs ETOPO5, TerrainBase and JGP95E. Physics and Chemistry of the Earth, Part A: Solid Earth and Geodesy, 25, 89-93. http://www.sciencedirect.com/science/article/pii/S1464189500000156 https://doi.org/10.1016/S1464-1895(00)00015-6

[6] Berthier, E., Arnaud, Y., Vincent, C. and Remy, F. (2006) Biases of SRTM in High-Mountain Areas: Implications for the Monitoring of Glacier Volume Changes. Geophysical Research Letters, 33. https://doi.org/10.1029/2006GL025862

[7] Fox, M., Dorrell, B. and Haskell, L. (2008) Got Mountains? Challenges of Modeling SRTM and Other Terrain Data to Suit Aviation Applications. Proceedings of Esri 28th Annual International User Conference, San Diego, California.

[8] Thomas, C.D., Cameron, A., Green, R.E., Bakkenes, M., Beaumont, L.J., Collingham, Y.C., Erasmus, B.F.N., de Siqueira, M.F., Grainger, A., Hannah, L., Hughes, L., Huntley, B., van Jaarsveld, A.S., Midgley, G.F., Miles, L., Ortega-Huerta, M.A., Townsend Peterson, A., Phillips, O.L. and Williams, S.E. (2004) Extinction Risk from Climate Change. Nature, 427, 145-148. https://doi.org/10.1038/nature02121 
[9] Erasmi, S., Rosenbauer, R., Buchbach, R., Busche, T. and Rutishauser, S. (2014) Evaluating the Quality and Accuracy of TanDEM-X Digital Elevation Models at Archaeological Sites in the Cilician Plain, Turkey. Remote Sensing, 6, 9475-9493. https://doi.org/10.3390/rs6109475

[10] Pope, A., Murray, T. and Luckman, A. (2007) DEM Quality Assessment for Quantification of Glacier Surface Change. Annals of Glaciology, 46, 189-194. https://doi.org/10.3189/172756407782871792

[11] Sarmiento, C.J.S., Gonzalez, R.M. and Castro, P.P.M. (2012) Reservoir Inflow Estimation Using Remote Sensing, GIS and Geosimulation. Journal of Earth Science and Engineering, 2, 472-487.

[12] Florinsky, I.V. (2016) Digital Terrain Analysis in Soil Science and Geology. 2nd Edition, Academic Press, Amsterdam.

[13] Hancock, G.R., Martinez, C., Evans, K.G. and Moliere, D.R. (2006) A Comparison of SRTM and High-Resolution Digital Elevation Models and Their Use in Catchment Geomorphology and Hydrology: Australian Examples. Earth Surface Processes and Landforms, 31, 1394-1412. https://doi.org/10.1002/esp.1335

[14] Du, X., Guo, H., Fan, X., Zhu, J., Yan, Z. and Zhan, Q. (2015) Vertical Accuracy Assessment of Freely Available Digital Elevation Models over Low-Lying Coastal Plains. International Journal of Digital Earth, 9, 252-271. https://doi.org/10.1080/17538947.2015.1026853

[15] Yap, L., Kandé, L.H., Nouayou, R., Kamguia, J., Ngouh, N.A. and Makuate, M.B. (2018) Vertical Accuracy Evaluation of Freely Available Latest High-Resolution (30 m) Global Digital Elevation Models over Cameroon (Central Africa) with GPS/Leveling Ground Control Points. International Journal of Digital Earth, 1-25. https://doi.org/10.1080/17538947.2018.1458163

[16] Hirt, C., Filmer, M.S. and Featherstone, W.E. (2010) Comparison and Validation of the Recent Freely Available ASTER-GDEM ver1, SRTM ver4. 1 and GEODATA DEM-9S ver3 Digital Elevation Models over Australia. Australian Journal of Earth Sciences, 57, 337-347. https://doi.org/10.1080/08120091003677553

[17] Varga, M. and Bašić, T. (2015) Accuracy Validation and Comparison of Global Digital Elevation Models over Croatia. International Journal of Remote Sensing, 36, 170-189. https://doi.org/10.1080/01431161.2014.994720

[18] Santillan, J.R. and Makinano-Santillan, M. (2016) Vertical Accuracy Assessment of 30-m Resolution ALOS, ASTER, and SRTM Global DEMs over Northeastern Mindanao, Philippines. The International Archives of the Photogrammetry, Remote Sensing and Spatial Information Sciences, XLI-B4, 149-156. https://doi.org/10.5194/isprsarchives-XLI-B4-149-2016

[19] Habib, A., Akdim, N., Labbassi, K., Khoshelham, K. and Menenti, M. (2017) Extraction and Accuracy Assessment of High-Resolution DEM and Derived Orthoimages from ALOS-PRISM Data over Sahel-Doukkala (Morocco). Earth Science Informatics, 10, 197-217. https://doi.org/10.1007/s12145-017-0287-5

[20] Purinton, B. and Bookhagen, B. (2017) Validation of Digital Elevation Models (DEMs) and Comparison of Geomorphic Metrics on the Southern Central Andean Plateau. Earth Surface Dynamics, 5, 211-237. https://doi.org/10.5194/esurf-5-211-2017

[21] Yamazaki, D., Ikeshima, D., Tawatari, R., Yamaguchi, T., O’Loughlin, F., Neal, J.C., Sampson, C.C., Kanae, S. and Bates, P.D. (2017) A High-Accuracy Map of Global Terrain Elevations. Geophysical Research Letters, 44, 5844-5853. https://doi.org/10.1002/2017GL072874

[22] Florinsky, I.V., Skrypitsyna, T.N. and Luschikova, O.S. (2018) Comparative Accu- 
racy of the AW3D30 DSM, ASTER GDEM, and SRTM1 DEM: A Case Study on the Zaoksky Testing Ground, Central European Russia. Remote Sensing Letters, 9, 706-714. https://doi.org/10.1080/2150704X.2018.1468098

[23] Dawod, G. and Al-Ghamdi, K. (2017) Reliability of Recent Global Digital Elevation Models for Geomatics Applications in Egypt and Saudi Arabia. Journal of Geographic Information System, 9, 685-698. https://doi.org/10.4236/jgis.2017.96043

[24] Elkhrachy, I. (2017) Vertical Accuracy Assessment for SRTM and ASTER Digital Elevation Models: A Case Study of Najran City, Saudi Arabia. Ain Shams Engineering Journal, 9, 1807-1817.

[25] JAXA (2017) ALOS Global Digital Surface Model "ALOS World 3D-30 m (AW3D30)". JAXA, Tsukuba. http://www.eorc.jaxa.jp/ALOS/en/aw3d30/

[26] USGS (2015) Earth Explorer. USGS, Earth Resources Observation and Science Center, Sioux Fall, SD. http://earthexplorer.usgs.gov

[27] Tadono, T., Nagai, H., Ishida, H., Oda, F., Naito, S., Minakawa, K. and Iwamoto, H. (2016) Generation of the $30 \mathrm{~m}$-Mesh Global Digital Surface Model by ALOS PRISM. The International Archives of the Photogrammetry, Remote Sensing and Spatial Information Sciences, XLI-B4, 157-162. https://doi.org/10.5194/isprsarchives-XLI-B4-157-2016

[28] Takaku, J., Tadono, T., Tsutsui, K. and Ichikawa, M. (2016) Validation of “AW3D” Global DSM Generated from ALOS PRISM. ISPRS Annals of the Photogrammetry, Remote Sensing and Spatial Information Sciences, III-4, 25-31. https://doi.org/10.5194/isprsannals-III-4-25-2016

[29] Tachikawa, T., Kaku, M., Iwasaki, A., Gesch, D.B., Oimoen, M.J., Zhang, Z., Danielson, J.J., Krieger, T., Curtis, B., Haase, J., et al. (2011) ASTER Global Digital Elevation Model Version 2-Summary of Validation Results. Tech. Rep., NASA.

[30] Farr, T.G., Rosen, P.A., Caro, E., Crippen, R., Duren, R., Hensley, S., Kobrick, M., Paller, M., Rodriguez, E., Roth, L., Seal, D., Shaffer, S., Shimada, J., Umland, J., Werner, M., Oskin, M., Burbank, D. and Alsdorf, D. (2007) The Shuttle Radar Topography Mission. Review of Geophysics, 45, RG2004. https://doi.org/10.1029/2005RG000183

[31] Lemoine, F.G., Kenyon, S.C., Factor, J.K., Trimmer, R.G., Pavlis, N.K., Chinn, D. S., et al. (1998) The Development of the Joint NASA GSFC and the National Imagery and Mapping Agency (NIMA) Geopotential Model EGM96.

[32] Smith, M.W. and Vericat, D. (2015) From Experimental Plots to Experimental Landscapes: Topography, Erosion and Deposition in Sub-Humid Badlands from Structure-from-Motion Photogrammetry. Earth Surface: Processes and Landforms, 40, 1656-1671. https://doi.org/10.1002/esp.3747

[33] Gesch, D.B., Oimoen, M.J., Danielson, J.J. and Meyer, D. (2016) Validation of the ASTER Global Digital Elevation Model Version 3 over the Conterminous United States. The International Archives of the Photogrammetry, Remote Sensing and Spatial Information Sciences, XLI-B4, 143-148.

https://pubs.er.usgs.gov/publication/70175051 https://doi.org/10.5194/isprsarchives-XLI-B4-143-2016

[34] Satge, F., Denezine, M., Pillco, R., Timouk, F., Pinel, S., Molina, J., Garnier, J., Seyler, F. and Bonnet, M.-P. (2016) Absolute and Relative Height-Pixel Accuracy of SRTM-GL1 over the South American Andean Plateau. ISPRS Journal of Photogrammetry and Remote Sensing, 121, 157-166.

https://www.sciencedirect.com/science/article/pii/S092427161630346X

https://doi.org/10.1016/j.isprsjprs.2016.09.003

[35] Grohmann, C.H. (2018) Evaluation of TanDEM-X DEMs on Selected Brazilian 
sites: Comparison with SRTM, ASTER GDEM and ALOS AW3D30. Remote Sensing of Environment, 212, 121-133. https://doi.org/10.1016/j.rse.2018.04.043

[36] Congalton, R.G. and Green, K. (2008) Assessing the Accuracy of Remotely Sensed Data: Principles and Practices, Second Edition (Mapping Science). CRC Press, Boca Raton. 